\title{
Optimasi Pengelompokan Data Pada Metode K-Means dengan Analisis Outlier
}

\author{
Pasek Agus Ariawan ${ }^{a, *}$ \\ ${ }^{a}$ Program Studi Magister Teknik elektro, Fakultas Teknik, Universitas Udayana, Bali, Indonesia
}

\begin{tabular}{|c|}
\hline INFORMASI ARTIKEL \\
\hline $\begin{array}{l}\text { Sejarah Artikel: } \\
\text { Diterima Redaksi: } 15 \text { Juli } 2019 \\
\text { Revisi Akhir: 04 September } 2019 \\
\text { Diterbitkan Online: } 19 \text { September } 2019\end{array}$ \\
\hline KATA KUNCI \\
\hline Clusterig, \\
\hline K-Means, \\
\hline Optimasi, \\
\hline Outlier \\
\hline KORESPONDENSI \\
\hline
\end{tabular}

E-mail: pasekagusariawan38@gmail.com

\begin{abstract}
A B S S T R A C $\mathbf{C}$
Data mining secara umum adalah proses analisis dan eksplorasi sejumlah besar data yang berbeda untuk menemukan pola yang bermakna. Berbagai teknik tersedia dalam data mining untuk ekstraksi pengetahuan antara lain klasifikasi, prediksi, estimasi, asosiasi dan pengelompokan. Salah satu metode pengelompokan yang terkenal adalah metode $K$-Means karena kesederhanaan dan efesiensinya, sehingga metode ini mudah diaplikasikan di berbagai bidang. Teknik pra-pemrosesan data diterapkan pada data mentah untuk membuat data bersih, bebas noise, dan konsisten, dalam data mining terdapat beberapa metode yang dapat digunakan tergantung dari tujuan yang akan dicapai. Deteksi outlier adalah penelitian dari data mining untuk mendeteksi kasus - kasus abnormal pada database. penelitian ini menggunakan metode local outlier factor untuk deteksi outlier dengan tujuan untuk mengatasi kekurangan dari metode $K$-Means yang sangat dipengaruhi oleh noise dan meningkatkan kualitas hasil cluster dari metode K-Means. Hasil dari penelitian, pengunaan metode local outlier factor pada data capaian kinerja pegawai dapat mendeteksi data outlier sebesar $22.8 \%$. Rata - rata iterasi, nilai SSE dan waktu komputasi untuk satu kali konvergen pada metode K-Means dengan analisis outlier memberikan hasil yang lebih baik untuk jumlah cluster 2 - 10 dibandingkan dengan metode $K$-Means tradisional.
\end{abstract}

\section{PENDAHULUAN}

Data dapat mengandung berbagai macam informasi yang dapat digunakan untuk berbagai keperluan seperti dalam pengambilan keputusan, interpretasi masa depan, perilaku pelanggan dan sebagainya. Dengan kemajuan teknologi saat ini, sejumlah data tidak hanya dapat dihasilkan, melainkan dapat juga dikomunikasikan dan disimpan melalu website. Selain website, sumber data lain yang tersedia adalah situs sosial media, halaman $w e b$, dll. Bidang yang berhubungan dengan ekstraksi pengetahuan dari data yang tersedia dikenal sebagai data mining. Data mining secara umum adalah proses analisis dan eksplorasi sejumlah besar data yang berbeda untuk menemukan pola yang bermakna. Berbagai teknik tersedia dalam data mining untuk ekstraksi pengetahuan antara lain klasifikasi, prediksi, estimasi, asosiasi dan pengelompokan. Dalam pengelompokan, cluster diatur sedemikian rupa sehingga objek dengan sifat yang serupa terletak pada satu cluster atau dengan kata lain objek dalam dua kelompok yang berbeda dapat memiliki sifat yang berbeda. Berbagai jenis pengelompokan adalah berbasis partisi, berbasis hierarkis, berbasis kepadatan, berbasis kisi dan berbasis model [1]. Salah satu metode pengelompokan yang terkenal adalah metode $K$-Means karena

https://doi.org/10.25077/ TEKNOSI.v5i2.2019.88-95 kesederhanaan dan efesiensinya, sehingga metode ini mudah diaplikasikan di berbagai bidang [2], seperti penelitian yang dilakukan sebelumnya [3] tentang penerapan metode $K$-Means dalam peningkatan mutu pembelajaran pada perguruan tinggi. Algoritma $K$-Means efektif dalam menghasilkan cluster untuk banyak aplikasi praktis. Algoritma ini menghasilkan berbagai jenis cluster tergantung pada pilihan acak centroid awal. Teknik prapemrosesan data diterapkan pada data mentah untuk membuat data bersih, bebas noise, dan konsisten. Normalisasi Data mengubah data mentah dengan mengubahnya menjadi rentang spesifik menggunakan transformasi linear yang dapat menghasilkan suatu cluster dengan kualitas yang baik, serta meningkatkan akurasi dari algoritma pengelompokan tersebut. Terdapat beberapa metode data mining yang dapat digunakan tergantung dari tujuan yang ingin dicapai. Deteksi outlier sebenarnya menemukan anomaly adalah penelitian dari untuk mendeteksi kasus - kasus abnormal pada database[4]. Menurut[5] dalam penelitian yang dilakukannya, metode $K$-Means dapat memetakan hasil produktivitas panen padi berdasarkan karakteristik datanya, hasil dari penelitian dapat memetakan data ke dalam 3 kelompok yaitu kurang dari target, sesuai target, dan melebihi target. Penelitian yang dilakukan sebelumnya[6] tentang rekomendasi kelompok belajar siswa dengan menggunakan teknik outlier di SDN pagelaran II, pada penelitian 
ini menggunakan metode local outlier factor untuk mendeteksi outlier pada data siswa kelas 6. Penelitian yang dilakukan oleh [7] ini mencakup studi perbandingan tentang berbagai algoritma deteksi outlier seperti deteksi outlier berbasis statistik, deteksi outlier berbasis kedalaman, teknik berbasis Clustering, deteksi outlier berbasis kepadatan dll. Studi perbandingan metode deteksi outlier ini dilakukan untuk mengetahui mana dari algoritma deteksi outlier yang lebih dapat diterapkan pada data dimensi tinggi. Penelitian yang dilakukan [8] bertujuan untuk mendeteksi pencilan pada set data campuran. Selanjutnya, mengkombinasikan algoritma dari beberapa teknik seperti subset cluster, outlier detection cluster based, dan Multiattribute Decision Making (MADM). Sebuah tes dilakukan terhadap set data dari UCI Machine Learning Repository. Evaluasi dilakukan untuk membandingkan rata-rata jangkauan yang mencapai rasio tertinggi antara jumlah pencilan yang tepat dan jumlah data. Dari tes, dapat disimpulkan bahwa MixCBLOF efektif untuk dideteksi outlier di set campuran data. Penelitian yang dilakukan [9] menyajikan solusi terdistribusi pertama untuk metode Local Outlier Factor (LOF) - teknik deteksi outlier populer yang terbukti sangat efektif untuk dataset yang besar. Seiring bertambahnya ukuran dataset secara radikal, algoritma LOF yang sangat skalabel yang memanfaatkan infrastruktur terdistribusi modern diperlukan. Ini menimbulkan tantangan signifikan karena kompleksitas definisi LOF, dan kurangnya akses ke seluruh dataset pada setiap proses penghitungan. Solusi kami menampilkan kerangka kerja pipa LOF terdistribusi, yang disebut DLOF. Penelitian lain tentang deteksi outlier dilakukan oleh [10] yang menyebutkan bahwa tujuan utama dari tahap data preprocessing adalah untuk mendeteksi outlier. Penelitian [11] bertujuan untuk mengatasi kekurangan metode $K$-Means yang sangat dipengaruhi oleh noise, penelitian yang dilakukan dengan mengimprovisasi metode $K$-Means dengan metode deteksi nosie percobaan dilakukan pada set data yang besar dengan hasil clustering ditingkatkan secara signifikan dan dampak data noise pada algoritma K-Means berkurang secara efektif dan hasil clustering lebih akurat.

Berdasarkan pemaparan penelitian [7], [10], [11], [14], [15] yang sudah dilakukan oleh peneliti terdahulu, maka pada penelitian ini menggunakan metode local outlier factor untuk deteksi outlier dengan tujuan untuk mengatasi kekurangan dari metode $\mathrm{K}$-Means yang sangat dipengaruhi oleh noise dan meningkatkan kualitas hasil cluster dari metode K-Means.

\section{METODE}

\subsection{Data Penelitian}

Penelitian ini menggunakan data sekunder yang berasal dari laporan capaian kinerja pegawai selama tahun 2017 di Univeristas Udayana. Fitur yang digunakan adalah nomor induk pegawai, nilai prilaku, nilai kehadiran, nilai kinerja. Ektraksi fitur dilakukan dengan cara mencari rata-rata nilai nilai prilaku, nilai kehadiran dan nilai kinerja.
Tabel 1. Potongan Data Cluster

\begin{tabular}{|c|c|c|c|c|}
\hline No & NIP & $\begin{array}{c}\text { Perilak } \\
\mathrm{u}\end{array}$ & Kehadiran & Kinerja \\
\hline 1 & '195403071980031004 & 93.67 & 100 & 155.372 \\
\hline 2 & '195612311982111001 & 81.6936 & 74.4136 & 125.395 \\
\hline 3 & '195710131980031003 & 95.094 & 74.232 & 94.036 \\
\hline 4 & '195712311979011005 & 89.8282 & 87.0991 & $\begin{array}{c}152.620 \\
5\end{array}$ \\
\hline 5 & '195809051981031003 & 87.895 & 90.9625 & 168 \\
\hline 6 & '195812311983032009 & 86.8811 & 95.8778 & 156.09 \\
\hline 7 & '195907271984031001 & 67.365 & 64.2213 & 84 \\
\hline 8 & '195909241986032003 & 87.855 & 75.335 & 168 \\
\hline 9 & '195910051981031004 & 90.895 & 62.1825 & 115.354 \\
\hline 10 & '195911251982112001 & 78.99 & 82.625 & $\begin{array}{c}141.657 \\
5 \\
\end{array}$ \\
\hline
\end{tabular}

\subsection{Tahapan Analisis}

Penelitian ini menggunakan data yang berasal dari laporan capaian kinerja pegawai selama tahun 2017 di Univeristas Udayana. Fitur yang digunakan adalah nomor induk pegawai, nilai prilaku, nilai kehadiran, nilai kinerja.

Berdasarkan gambar 1 penelitian akan dilakukan dengan membandingkan metode $K$-Means menggunakan metode local outlier factor untuk proses dekteksi outlier dengan metode $K$ Means tradisional. Adapun tahapan normalisasi adalah untuk menyamakan rentang nilai antara fitur yang akan diuji.

Tahapan pengujian akan dilakukan dengan melihat jumlah iterasi, nilai SSE dan waktu proses konvergen pada metode $K$-Means menggunakan metode local outlier factor untuk proses dekteksi outlier dan metode K-Means tradisional. Pengujian dengan metode SSE dilakukan untuk pengukuran kualitas dari cluster yang terbentuk.

Tahapan analisis perbandingan akan dilakukan dengan membandingkan jumlah iterasi, nilai SSE dan waktu proses konvergen pada metode $K$-Means menggunakan metode local outlier factor untuk proses dekteksi outlier dan metode $K$-Means tradisional, kemudian menentukan pengaruh dari metode LOF pada proses klasterisasi. Pengujian dilakukan sebanyak 3 kali pengulangan, kemudian dicari rata-rata dari jumlah iterasi, nilai SSE dan waktu proses konvergen. 


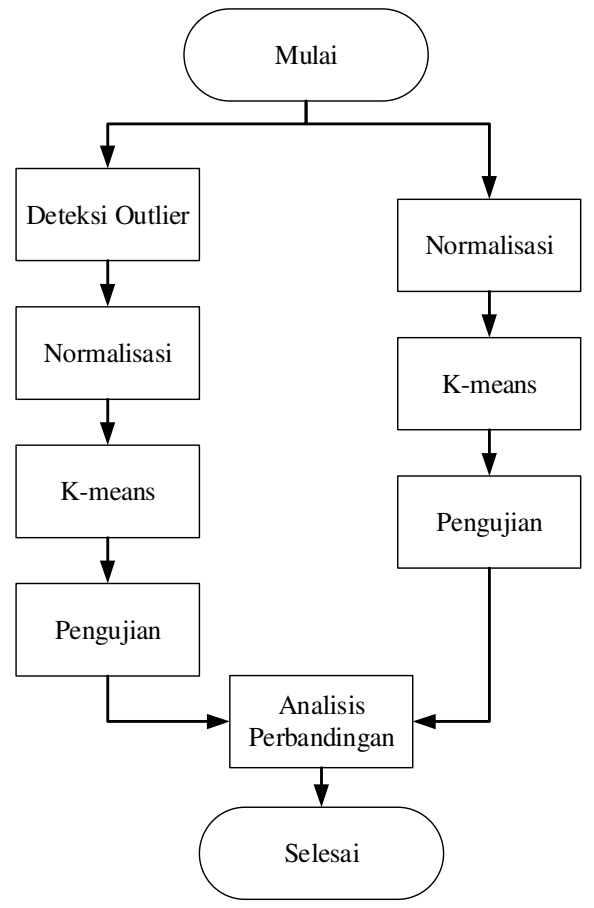

Gambar 1. Alur Proses Penelitian.

\section{HASIL DAN PEMBAHASAN}

\subsection{Hasil Deteksi Outlier}

Pada algoritma local outlier factor ini, hal-hal yang diperhatikan adalah menentukan banyakanya nilai minpts, minpts adalah jumlah tetangga terdekat yang akan digunakan untuk menghitung nilai outlier. Kemudian menentukan nilai batas dalam memilih suatu anomaly.

Tabel 2. Hasil Deteksi Outlier.

\begin{tabular}{ccccc}
\hline Minpts & \multicolumn{2}{c}{ Outlier } & \multicolumn{2}{c}{ Normal } \\
\cline { 2 - 5 } & Data & Presentase & Data & Presentase \\
\hline 100 & 159 & $22.6 \%$ & 546 & $77.4 \%$ \\
\hline 150 & 162 & $23.0 \%$ & 543 & $77.0 \%$ \\
\hline 200 & 161 & $22.8 \%$ & 544 & $77.2 \%$ \\
\hline 250 & 157 & $22.3 \%$ & 548 & $77.7 \%$ \\
\hline 300 & 152 & $21.6 \%$ & 553 & $78.4 \%$ \\
\hline 350 & 151 & $21.4 \%$ & 554 & $78.6 \%$ \\
\hline 400 & 146 & $20.7 \%$ & 559 & $79.3 \%$ \\
\hline 450 & 134 & $19.0 \%$ & 571 & $81.0 \%$ \\
\hline 500 & 121 & $17.2 \%$ & 584 & $82.8 \%$ \\
\hline
\end{tabular}

Pengujian outlier dilakukan untuk melakukan filter pada data - data yang memliki karakteristik yang berbeda dari data lainnya.
Pengujian dilakukan pada jumlah minpts yang telah ditentukan yaitu 100, 150, 200, 250, 300, 350, 400, 450, 500. Hasil deteksi outlier dapat dilihat pada tabel 2 .

Dari tabel dapat dibuat grafik hasil deteksi outlier dengan metode local outlier factor.Gambar 2 menunjukan hasil deteksi outlier dengan metode local outlier factor, dimana menunjukan hasil deteksi tertinggi pada minpts 150 sebesar 23\%, kemudian mengalami penurunan hasil deteksi hal ini diakibatkan oleh Semakin tingginya nilai minpts bararti semakin luas pula kepadatan objek tersebut. Data normal pada hasil deteksi dengan nilai minpts 150 kemudian akan digunakan untuk proses clustering.

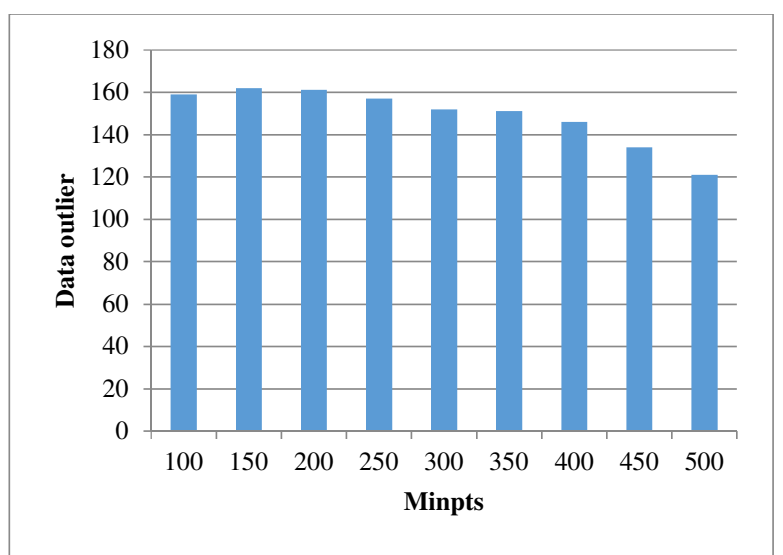

Gambar 2. Grafik Hasil Deteksi Outlier

\subsection{Normalisasi Min-Max}

Normalisasi bertujuan untuk menskalakan nilai dari fitur yang digunakan pada penelitian ini memiliki rentang yang sama dari 0-1. Tabel 3 merupakan potongan data awal sebelum dilakukan proses transformasi. Tabel 3 menunjukan hasil dari transformasi yang telah dilakukan.

Dari tabel 3 kemudian dilakukan perhitungan dengan menggunakan rumus 3. Hasil dari perhitungan ditampilkan pada tabel 4, dimana dapat dilihat terjadi perubahan nilai pada setiap fitur yang digunakan pada penelitian, yang semula miliki rentang nilai yang berbeda, kemudian setelah proses transformasi memiliki rentang nilai yang sama.

Tabel 3. Potongan Data Awal Sebelum Transformasi.

\begin{tabular}{rrr}
\multicolumn{1}{l}{ Perilaku } & Kehadiran & \multicolumn{1}{l}{ Kinerja } \\
\hline 93.67 & 100 & 155.372 \\
\hline 81.69364 & 74.41364 & 125.395 \\
\hline 95.094 & 74.232 & 94.036 \\
\hline 89.82818 & 87.09909 & 152.6205 \\
\hline 87.895 & 90.9625 & 168 \\
\hline 86.88111 & 95.87778 & 156.09 \\
\hline 67.365 & 64.22125 & 84 \\
\hline 87.855 & 75.335 & 168 \\
\hline & &
\end{tabular}


Tabel 4. Potongan Data Awal Sebelum Transformasi.

\begin{tabular}{rrr}
\hline \multicolumn{1}{l}{ Perilaku } & Kehadiran & \multicolumn{1}{l}{ Kinerja } \\
\hline 0.939794 & 1 & 0.918498 \\
\hline 0.757167 & 0.707985 & 0.725024 \\
\hline 0.961509 & 0.705912 & 0.522631 \\
\hline 0.88121 & 0.852763 & 0.90074 \\
\hline 0.851731 & 0.896856 & 1 \\
\hline 0.836271 & 0.952953 & 0.923132 \\
\hline 0.53867 & 0.59166 & 0.457858 \\
\hline 0.851121 & 0.7185 & 1
\end{tabular}

\subsection{Hasil Pengujian Rata- Rata Jumlah Iterasi Dalam Satu Kali Konvergen Pada K-Means + LOF Dengan K-Means Tradisional}

Pada pengujian pertama dilakukan untuk membandingan rata - rata jumlah iterasi yang diperlukan untuk mencapai kondisi konvergen antara metode $K$-Means menggunakan metode local outlier factor untuk proses dekteksi outlier dengan K-Means tradisional.
Pengujian dilakukan sebanyak tiga kali percobaan dengan perubahan jumlah cluster yang diuji. Pengujian dilakukan pada jumlah cluster 2-10. Hasil rata - rata jumlah iterasi dapat dilihat pada tabel 5 .

\begin{tabular}{ccc}
\multicolumn{3}{c}{ Tabel 5. Hasil Perbandingan Rata-Rata Iterasi } \\
\hline $\mathbf{K}$ & \multicolumn{2}{c}{ Iterasi } \\
\cline { 2 - 3 } & K-Means+LOF & K-Means \\
\hline $\mathbf{2}$ & 6.666666667 & 7 \\
\hline $\mathbf{3}$ & 9 & 9.66666667 \\
\hline $\mathbf{4}$ & 9 & 18 \\
\hline $\mathbf{5}$ & 11.66666667 & 17 \\
\hline $\mathbf{6}$ & 10.33333333 & 14.6666667 \\
\hline $\mathbf{7}$ & 10.33333333 & 16.6666667 \\
\hline $\mathbf{8}$ & 12.66666667 & 17.3333333 \\
\hline $\mathbf{9}$ & 12.66666667 & 18 \\
\hline $\mathbf{1 0}$ & 14.66666667 & 18 \\
\hline
\end{tabular}

Dari tabel 5 dapat dibuat grafik hasil perbandingan uji coba ratarata jumlah iterasi yang diperlukan untuk satu kali konvergen.

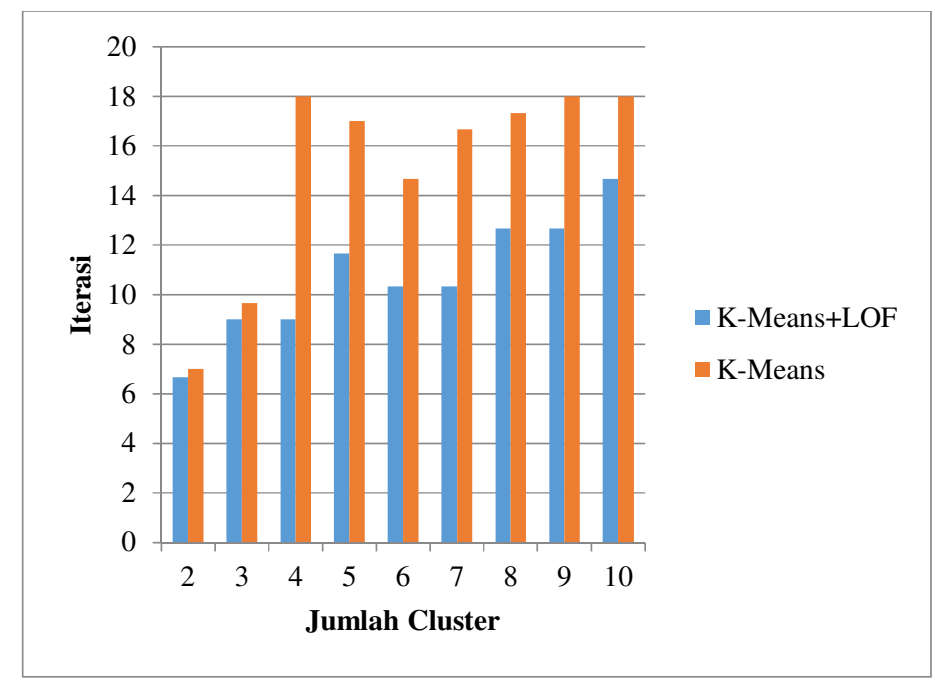

Gambar 3. Grafik Perbandingan Hasil Iterasi

Gambar 3 menunjukan hasil metode K-Means dengan analisis outlier memiliki rata - rata nilai iterasi yang lebih kecil dari metode $K$-Means tradisional. Hal ini menunjukan bahwa jumlah pengulangan pembetukan cluster untuk mencapai kondisi konvergen dengan metode $K$-Means dengan analisis outlier lebih cepat dibandingkan metode $K$-Means tradisional.

\subsection{Hasil Pengujian Rata- Rata Nilai Sum Of Square Error Dalam Satu Kali Konvergen Pada K-Means + LOF Dengan K-Means Tradisional}

Pada pengujian kedua dilakukan untuk membandingan rata - rata hasil Sum of Square error pada kondisi satu kali konvergen antara metode $K$-Means menggunakan metode local outlier factor untuk proses dekteksi outlier dengan K-Means tradisional. Pengujian dilakukan sebanyak tiga kali percobaan dengan perubahan jumlah 
cluster yang diuji. Pengujian dilakukan pada jumlah cluster 2-10. Hasil rata - rata hasil Sum of Square error dapat dilihat pada tabel 6.

Dari tabel 6 dapat dibuat grafik hasil perbandingan uji coba rata rata nilai Sum of Square error pada kondisi satu kali konvergen. Gambar 4 menunjukan hasil K-Means dengan analisis outlier memiliki rata - rata nilai Sum of Square error yang lebih kecil dibandingkan $K$-Means tradisional. Ini menunjukan bahwa entitas yang masuk pada jumlah cluster metode $K$-Means dengan analisis outlier memiliki kesamaan yang lebih seragam dari pada entitas yang ada pada jumlah cluster K-Means tradisional.
Tabel 6. Hasil Perbandingan Sum Of Square Error

\begin{tabular}{ccc}
\hline $\mathrm{K}$ & \multicolumn{2}{c}{ Sum of Square error } \\
\cline { 2 - 3 } & K-Means+LOF & K-Means \\
\hline 2 & 2.500266667 & 21.5294 \\
\hline 3 & 1.824433333 & 17.916867 \\
\hline 4 & 1.329533333 & 14.647333 \\
\hline 5 & 1.1644 & 11.886333 \\
\hline 6 & 1.0572 & 10.940833 \\
\hline 7 & 0.915866667 & 9.2099667 \\
\hline 8 & 0.856533333 & 7.8622667 \\
\hline 9 & 0.766033333 & 6.972 \\
\hline 10 & 0.676366667 & 6.4364333
\end{tabular}

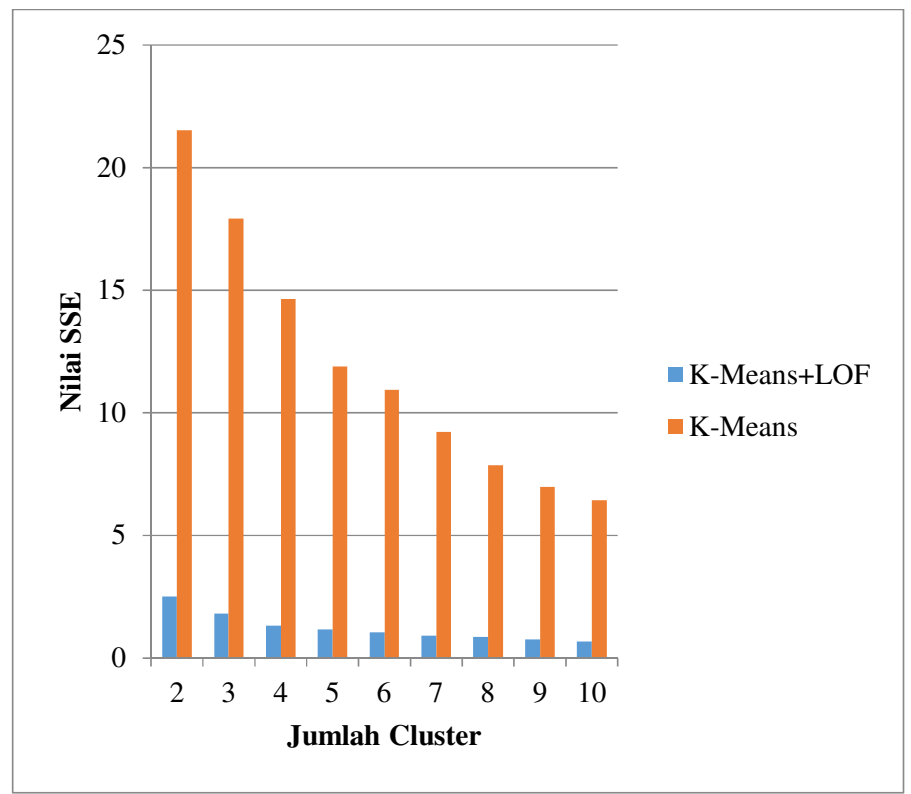

Gambar 4. Grafik Perbandingan Hasil Sum Of Square Error

\subsection{Hasil Pengujian Rata- Rata Waktu Dalam Satu Kali Konvergen Pada K-Means + LOF Dengan K- Means Tradisional}

Pada pengujian Ketiga dilakukan untuk membandingan rata - rata waktu yang diperlukan untuk kondisi satu kali konvergen antara metode $K$-Means menggunakan metode local outlier factor untuk proses dekteksi outlier dengan K-Means tradisional. Pengujian dilakukan sebanyak tiga kali percobaan dengan perubahan jumlah cluster yang diuji. Pengujian dilakukan pada jumlah cluster 2-10. Hasil rata - rata waktu dapat dilihat pada tabel 7.
Tabel 7. Hasil Perbandingan Waktu

\begin{tabular}{ccc}
\hline $\mathrm{K}$ & \multicolumn{2}{c}{ Waktu } \\
\cline { 2 - 3 } & K-Means+LOF & K-Means \\
\hline 2 & 0.431266333 & 0.540047333 \\
\hline 3 & 0.382809667 & 1.061490333 \\
\hline 4 & 0.480251333 & 1.182051667 \\
\hline 5 & 0.488963667 & 1.385132667 \\
\hline 6 & 0.693024333 & 0.933994 \\
\hline 7 & 0.800864333 & 1.713181667 \\
\hline 8 & 0.798506333 & 1.438461667 \\
\hline 9 & 0.864796333 & 1.635548 \\
\hline 10 & 1.106676667 & 1.213016667
\end{tabular}


Dari tabel 7 dapat dibuat grafik hasil perbandingan uji coba rata rata waktu yang diperlukan untuk kondisi satu kali konvergen.

Gambar 5 menunjukan hasil K-Means dengan analisis outlier memiliki rata - rata waktu untuk mencapai satu kali konvergen yang lebih kecil dibandingkan K-Means tradisional. Ini menunjukan bahwa waktu komputasi yang diperlukan metode $K$-Means dengan analisis outlier lebih cepat daripada K-Means tradisional dikarenakan data yang memilki karakteristik yang jauh berbeda telah dihilangkan pada proses pengelompokan data.

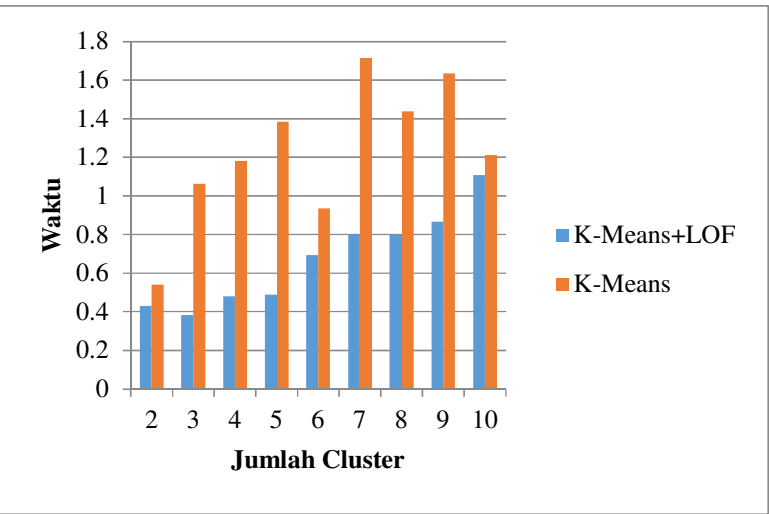

Gambar 5. Grafik Perbandingan Waktu Untuk Satu Kali Konvergen.

\section{KESIMPULAN}

Berdasarkan hasil dari penelitian dapat disimpulkan bahwa Pengunaan metode local outlier factor pada data capaian kinerja pegawai dapat mendeteksi data outlier sebesar $22.8 \%$ dan dengan menggunakan metode local outlier factor dapat memberikan hasil yang lebih optimal pada pengelompokan data dengan metode $K$ Means baik dari jumlah iterasi, waktu pemrosesan dan kualitas cluster.

Metode local outlier factor untuk dekteksi outlier sangat sensitiif terhadap nilai parameter minpts untuk menentukan jumlah tetangga terdekat. Oleh karena itu diperlukan suatu metode yang dapat menetukan jumlah minpts yang optimal pada metode local outlier factor.

\section{DAFTAR PUSTAKA}

[1] V. Bhatt, M. Dhakar, Dan B. K. Chaurasia, "Filtered Clustering Based On Local Outlier Factor In Data Mining," Int. J. Database Theory Appl., Vol. 9, No. 5, Hal. 275-282, 2016.

[2] G. Gustientiedina, M. H. Adiya, Dan Y. Desnelita, "Jurnal Nasional Teknologi Dan Sistem Informasi
Penerapan Algoritma K-Means Untuk Clustering Data Obat-Obatan Pada Rsud Pekanbaru," J. Nas. Teknol. Dan Sist. Inf., Vol. 05, No. 01, Hal. 17-24, 2019.

[3] K. Handoko, "Penerapan Data Mining Dalam Meningkatkan Mutu Pembelajaran Pada Instansi Perguruan Tinggi Menggunakan Metode K - Means Clustering ( Studi Kasus Di Program Studi Tkj Akademi Komunitas Solok Selatan )," Vol. 02, No. 03, Hal. 31-40, 2016.

[4] K. G. Sharma, Y. Singh, Dan A. K. Srivastava, "Variance On Outlier Factor," In Impact, 2017, Hal. 101-103.

[5] M. R. Ridlo, S. Defiyanti, Dan A. Primajaya, "Implementasi Algoritme K-Means Untuk Pemetaan Produktivitas Panen Padi Di Kabupaten Karawang," In Citee 2017, 2017, Hal. 426-433.

[6] N. Idham, "Penerapan Outlier Analysis Sebagai Salah Satu Rekomendasi Kelompok Belajar Terhadap Siswa Kelas 6 Di Sdn Pagelaran Ii Program Studi Teknik Informatika," Universitas Komputer Indonesia, 2017.

[7] K. Kaur Dan A. Garg, "Comparative Study Of Outlier Detection Algorithms," Int. J. Comput. Appl. (0975, Vol. 147, No. 9, Hal. 21-26, 2016.

[8] D. Maryono Dan A. Djunaidy, "Berbasis Klaster Pada Set Data Dengan Atribut Campuran Numerik Dan Kategorikal *," J. Ilm. Kursor, Vol. 5, No. 3, Hal. 197-204, 2010.

[9] Y. Yan, L. Cao, C. Kuhlman, Dan E. Rundensteiner, "Distributed Local Outlier Detection In Big Data," In Kdd 2017 Research Paper, 2017, Hal. 1225-1234.

[10] A. Mahendra, "Pentapisan Dan Deteksi Data Outlier Dalam Proses Sistem Akusisi Data Pada Proses Sintering," Arsitron, Vol. 6, No. 1, Hal. 1-7, 2015.

[11] J. Wang Dan X. Su, "An Improved K-Means Clustering Algorithm," In 2011 Ieee 3rd International Conference On Communication Software And Networks, 2011, Hal. 44-46.

[12] G. Ngurah, W. Paramartha, D. E. Ratnawati, Dan A. W. Widodo, "Analisis Perbandingan Metode $K$ Means Dengan Improved Semi- Supervised $K$ Means Pada Data Indeks Pembangunan Manusia ( Ipm )," Vol. 1, No. 9, Hal. 813-824, 2017.

[13] R. Pamula, J. K. Deka, Dan S. Nandi, "An Outlier Detection Method Based On Clustering," In Second 
International Conference On Emerging Applications Of Information Technology, 2011, Hal. 253-256.

[14] B. Santoso, I. Cholissodin, Dan B. D. Setiawan, "Optimasi K-Means Untuk Clustering Kinerja Akademik Dosen Menggunakan Algoritme Genetika," J. Pengemb. Teknol. Inf. Dan Ilmu Komput., Vol. 1, No. 12, Hal. 1652-1659, 2017.

[15] E. A. Sari, "Penerapan Algoritma K-Means Untuk Menentukan Tingkat Kesehatan Bayi Dan Balita Pada Kabupaten Dan Kota Di Jawa Tengah," Universitas Dian Nuswantoro, 2015.

\section{BIODATA PENULIS}

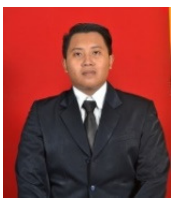

Pasek Agus Ariawan

Mahasiswa asal kota Denpasar yang sedang menempuh studi S-2 Konsentrasi Manajemen Sistem Informasi dan Komputer Pada Program Magister Teknik Eletro Universitas Udayana.

\section{LAMPIRAN}

Tabel 8. Hasil Pengujian Iterasi Pada Percobaan 1

\begin{tabular}{ccc}
\hline \multirow{2}{*}{$\mathrm{K}$} & \multicolumn{2}{c}{ Iterasi } \\
\cline { 2 - 3 } & K-Means+LOF & K-Means \\
\hline 2 & 6 & 7 \\
3 & 12 & 7 \\
4 & 8 & 5 \\
5 & 11 & 24 \\
6 & 9 & 16 \\
7 & 9 & 16 \\
8 & 12 & 20 \\
9 & 14 & 21 \\
10 & 12 & 11 \\
\hline
\end{tabular}

Tabel 9. Hasil Pengujian Iterasi Pada Percobaan 2

\begin{tabular}{ccc}
\hline \multirow{2}{*}{ K } & \multicolumn{2}{c}{ Iterasi } \\
\cline { 2 - 3 } & K-Means+LOF & K-Means \\
\hline 2 & 8 & 8 \\
3 & 9 & 12 \\
4 & 6 & 23 \\
5 & 16 & 22 \\
6 & 10 & 17 \\
7 & 8 & 13 \\
8 & 14 & 17 \\
9 & 12 & 22 \\
10 & 20 & 24 \\
\hline
\end{tabular}

Tabel 10. Hasil Pengujian Iterasi Pada Percobaan 3

\begin{tabular}{ccc}
\hline \multirow{2}{*}{$\mathrm{K}$} & \multicolumn{2}{c}{ Iterasi } \\
\cline { 2 - 3 } & K-Means+LOF & K-Means \\
\hline 2 & 6 & 6 \\
3 & 6 & 10 \\
4 & 13 & 26 \\
5 & 8 & 5 \\
6 & 12 & 11 \\
7 & 14 & 21 \\
8 & 12 & 15 \\
9 & 12 & 11 \\
10 & 12 & 19 \\
\hline
\end{tabular}

Tabel 11. Hasil Pengujian Waktu Pada Percobaan 1

\begin{tabular}{ccc}
\hline \multirow{2}{*}{$\mathrm{K}$} & \multicolumn{2}{c}{ Waktu } \\
\cline { 2 - 3 } & K-Means + LOF & K-Means \\
\hline 2 & 0.522175 & 0.538862 \\
3 & 0.312443 & 1.12754 \\
4 & 0.552798 & 1.313103 \\
5 & 0.497257 & 1.630778 \\
6 & 0.79325 & 1.091953 \\
7 & 0.648713 & 1.861853 \\
8 & 0.981664 & 0.898478 \\
9 & 1.217023 & 1.575833 \\
10 & 0.878183 & 1.079117 \\
\hline
\end{tabular}

Tabel 12. Hasil Pengujian Waktu Pada Percobaan 2

\begin{tabular}{ccc}
\hline \multirow{2}{*}{$\mathrm{K}$} & \multicolumn{2}{c}{ Waktu } \\
\cline { 2 - 3 } & K-Means + LOF & K-Means \\
\hline 2 & 0.463846 & 0.615985 \\
3 & 0.381861 & 1.180875 \\
4 & 0.497465 & 1.415759 \\
5 & 0.508844 & 1.817307 \\
6 & 0.892226 & 0.747121 \\
7 & 0.954732 & 0.979184 \\
8 & 0.824129 & 2.019399 \\
9 & 0.73207 & 1.806 \\
10 & 1.017441 & 0.963188 \\
\hline
\end{tabular}

Tabel 13. Hasil Pengujian Waktu Pada Percobaan 3

\begin{tabular}{ccc}
\hline \multirow{2}{*}{$\mathrm{K}$} & \multicolumn{2}{c}{ Waktu } \\
\cline { 2 - 3 } & K-Means+LOF & K-Means \\
\hline 2 & 0.307778 & 0.465295 \\
3 & 0.454125 & 0.876056 \\
4 & 0.390491 & 0.817293 \\
5 & 0.46079 & 0.707313 \\
6 & 0.393597 & 0.962908 \\
7 & 0.799148 & 2.298508 \\
8 & 0.589726 & 1.397508 \\
9 & 0.645296 & 1.524811 \\
10 & 1.424406 & 1.596745 \\
\hline
\end{tabular}


Tabel 14. Hasil Pengujian SSE Pada Percobaan 1

\begin{tabular}{ccc}
\hline \multirow{2}{*}{$\mathrm{K}$} & \multicolumn{2}{c}{ Sum of Square error } \\
\cline { 2 - 3 } & K-Means + LOF & K-Means \\
\hline 2 & 2.4999 & 21.5294 \\
3 & 1.8247 & 19.2127 \\
4 & 1.3301 & 14.9065 \\
5 & 1.1455 & 11.8157 \\
6 & 1.0433 & 10.9729 \\
7 & 0.9054 & 9.3037 \\
8 & 0.8732 & 7.4657 \\
9 & 0.7659 & 6.884 \\
10 & 0.6644 & 6.0888 \\
\hline
\end{tabular}

Tabel 15. Hasil Pengujian SSE Pada Percobaan 2

\begin{tabular}{ccc}
\hline \multirow{2}{*}{ K } & \multicolumn{2}{c}{ Sum of Square error } \\
\cline { 2 - 3 } 2 & K-Means+LOF & K-Means \\
3 & 2.501 & 21.5294 \\
4 & 1.8244 & 17.7029 \\
5 & 1.3289 & 14.3408 \\
6 & 1.202 & 11.9292 \\
7 & 1.0912 & 10.3026 \\
8 & 0.9157 & 9.1187 \\
9 & 0.8374 & 8.6696 \\
10 & 0.7714 & 7.0202 \\
& 0.6805 & 6.617 \\
\hline & & \\
Tabel 16. Hasil Pengujian SSE Pada Percobaan 3 \\
\hline \multirow{2}{*}{ K } & \multicolumn{2}{c}{ Sum of Square error } \\
\cline { 2 - 3 } 2 & K-Means+LOF & K-Means \\
\hline 3 & 2.4999 & 21.5294 \\
4 & 1.8242 & 16.835 \\
5 & 1.3296 & 14.6947 \\
6 & 1.1457 & 11.9141 \\
7 & 1.0371 & 11.547 \\
8 & 0.9265 & 9.2075 \\
9 & 0.859 & 7.4515 \\
10 & 0.7608 & 7.0118 \\
\hline
\end{tabular}

